\title{
Atık Su ile Sulanan Mısır Bitkisinde Makro ve Mikro Element ve Ağır Metal Birikimi
}

\author{
Șerife CAY1,* \\ Rıza KANBER² \\ 'Toprak su ve Çölleșme ile Mücadele Araștırma Enstitüsü. Konya \\ ${ }^{2}$ Çukurova Üniversitesi Ziraat F., Tarımsal Yapılar ve Sulama Anabilim Dalı.Adana
}

\begin{abstract}
*Sorumlu yazar e-mail (Corresponding author e-mail): serifecay@tarim.gov.tr
Geliș tarihi (Received) : 08.10.2020

Kabul tarihi (Accepted): 30.10.2020

DOI: $10.21657 /$ topraksu.807495
\end{abstract}

\section{Öz}

Bu çalıșmanın amacı, günümüzde artan kentleșmeye bağı olarak deșarjı da artan atık suların arıtılarak ve seyreltilerek bitkisel üretimde yeniden değerlendirilmesine yöneliktir. Denemede kullanılan sularla yetiștirilen mısır bitkisinin farklı organlarında $\mathrm{N}, \mathrm{P}, \mathrm{K}, \mathrm{Ca}, \mathrm{Mg}$ gibi makro elementler ile $\mathrm{Fe}, \mathrm{Cu}$, $\mathrm{Zn}, \mathrm{Mn}$ gibi iz elementleri ve $\mathrm{Pb}, \mathrm{Ni}, \mathrm{Cd}$ ve $\mathrm{B}$ gibi ağır metallerin analizleri yapıımıștır. Arıtma tesislerinin hizmete girmesiyle marinal suların tarımda kullanım seçeneğinin getireceği olumlu olumsuz etkilerin incelenmesi yapılmıștır. Ancak, tuzluluk kontrolü, mikrobiyolojik arıtım ve ağır metal arııımı yapıımadan, atık ve atık su kaynaklı karıșımların kullanııması, toprakların çoraklașmasını ve mikrobiyal kirlenme oranını ve kirlenmenin sürekliliğini önemli ölçüde etkileyeceği sonucuna ulașılmıștır.

Anahtar Kelimeler: Kentsel atık su, atık su kaynaklı sular, Konya, mısır (Zea mays), bitki analizleri, ağır metaller

\section{Heavy Metal Accumulation with Macro and Micro Elements in Maize Plant Irrigated by Wastewater}

\section{Abstract}

In this study, wastewater based on today's increasing urbanization, the increasing discharge of it, by treatment and mixing equal amounts for reuse in agricultural production have been assessed. The conclusion has been reached that maize can be grown using waste water in agriculture but significantly would affect without controlling of the heavy metal treatment.Macro elements such as $\mathrm{N}, \mathrm{P}, \mathrm{K}, \mathrm{Ca}, \mathrm{Mg}$, trace elements such as $\mathrm{Fe}, \mathrm{Cu}, \mathrm{Zn}, \mathrm{Mn}$, and heavy metals such as $\mathrm{Pb}, \mathrm{Ni}, \mathrm{Cd}$ and $\mathrm{B}$ were analyzed on different organs of the maize plant grown with the water used in the trial.Upon entering service of treatment plants the positive and negative effects of waste waters in agriculture were examined. It was concluded that the use of waste and wastewater-derived mixtures would significantly affect the wasteland of soils and the rate of microbial contamination and the continuity of contamination

Keywords: Urban waste water, waste water source water, Konya, maize (Zea Mays), plant analysis, heavy metals.

\section{Gíris}

Son dönemlerde arıtılmıș atık su kullanımı konusu, ülkemizde de giderek artan oranda ilgi görmektedir. Atık suların kullanılması, bitki koruma, hidroloji, gübreleme ve çevre ve halk sağlığı konuları ile birlikte dikkate alınması gerekir.
Kentsel gelișmeye bağlı olarak, giderek artan oranda elde edilen atık suların, bitkisel üretimde kullanılma olanaklarının araștırıması, sınırlııklarının, üstünlüklerinin anlașıması, bu çalıșmanın bir bașka amacını olușturmaktadır. Böylece, atık 
suların yeniden değerlendirilerek tarımsal amaçla kullanılabilmelerine ilișkin gerekli bilgiler sağlanacak, toprak ve su kaynakları üzerindeki etkileri öğrenilebilecektir. Çalıșmada TAGEM 2013-51 Nolu Proje sonuç raporuna göre marjinal suların bitki de kök gövde yaprak ve danede birikimleri incelenmiștir.

Araștırma, Konya Toprak ve Su Kaynakları Araștırma Enstitü Müdürlüğü merkez arazisinde bulunan araștırma alanında yürütülmüștür.

Denemede atık su, arıtılmıș atık su ve temiz su ve bu suların eșit miktarda (1:1) karıșımları kullanılmıștır. Deneme konularını, değinilen bu sular olușturmuștur. Buna göre denemede, kentsel atık su (KS), arıtılmıș atık su (AS) ve temiz su (TS) ile bunların karıșımları, olan kentsel atık su ve arıtılmıș atık su (KS+AS), kentsel atık su ve temiz su (KS+TS) ile arıtılmıș atık su ve temiz su (AS+TS) konuları ele alınmıștır.

\section{ARAȘTIRMA BULGULARI}

Denemede kullanılan sularla yetiștirilen mısır bitkisinin farklı organlarında N, P, K, Ca, Mg gibi makro elementler ile $\mathrm{Fe}, \mathrm{Cu}, \mathrm{Zn}, \mathrm{Mn}$ gibi iz elementleri ve $\mathrm{Pb}$, $\mathrm{Ni}, \mathrm{Cd}$ ve B gibi ağır metallerin analizleri yapılmıștır. Bitkinin kök, gövde, yaprak ve danelerinde, hasat döneminde yapılan analizler sonucunda, elde edilen bulgular Çizelge l'de verilmiștir.

Denemenin her iki yılında bitkinin kök, gövde, yaprak ve danesinde azot içeriği, diğer konulara göre, KS konusunda; bitki organlarına göre ise danede yüksektir. Azot birikimi, denemenin birinci yılında; en fazla dane ve yaprakta, KS ve AS+KS konularında; ikinci yılında ise, bitkinin tüm organlarında KS konusunda en yüksek olarak saptanmıștır (Çizelge 1-4). Day ve ark. (1975) kentsel atık suların buğday bitkisinde, Day ve Tucker (1977) sorgum bitkisinde, Marten ve ark. (1980) mısır bitkisinde, toprak üstü aksam ve dane azot içeriğini artırdığını bildirmișlerdir.

Fosfor içeriği, denemenin birinci yılında KS ve AS+KS konularında köklerde yüksek, danede az iken diğer konularda tersi durum söz konusudur. Bitki organlarına göre en az birikim gövdede saptanmıștır. Denemenin ikinci yılında, AS, TS+AS ve AS+KS konularında köklerde $P$ birikimi daha fazladır. Gövde ve yapraklarda fosfor içeriği, konular arasında farklı değildir. Danede ise TS+KS konusu en fazla P içeriğine sahiptir (Çizelge 1-4).

Potasyum, denemenin birinci yılında, en fazla köklerde, en az danede birikim göstermiștir. Ancak, danede en yüksek birikim KS konusunda saptanmıștır. AS, TS ve TS+KS konularında kökte,
TS konusunda gövdede ve KS konusunda yaprakta yüksek bulunmuștur. Denemenin ikinci yılında kök ve gövdede kirlilik yükü fazla olan (KS ve AS+KS) konularında artmıștır. AS konusunda, yaprakta, TS konusunda danede yüksek olarak saptanmıștır. Mısır bitkisinin denemenin birinci yılı kök haricinde bitkinin tüm organlarında potasyum içeriğinin düșük olduğu görülmüștür (Çizelge 1-4).

Kalsiyum içeriği, denemenin birinci yılında AS, TS+AS; denemenin ikinci yılında ise AS, TS, AS+KS ve KS konularında kökte yüksek iken, denemenin her iki yılında da gövde, yaprak ve danede KS konusunda, yüksek saptanmıștır (Çizelge 4. 16-19).

Magnezyum içeriği, denemenin ilk yılında kökte AS+KS ve KS konularında, gövde ve yaprakta TS konusunda, danede ise KS konusunda yüksektir. Denemenin ikinci yılında ise AS+KS, KS ve AS konularında kökte, AS ve KS konularında gövdede, KS konusunda yaprakta, KS, TS+KS ve AS konularında danede yüksek bulunmuștur (Çizelge 1-4).

Elde edilen bulgulara göre, atıksuların bitkininazot, fosfor, potasyum, kalsiyum ve magnezyum içeriğini artırdığı, benzer çalıșmalarda desteklenmektedir. Eid ve Shereif (1996), Kaçar ve Katkat (1998), Tuna ve ark. (2001), Tuna ve Bürün (2003), atık suların, mısır bitkisinin beslenmesini olumlu etkilediği ve yapraklarda makro ve mikro besin elementlerinin düzeylerinde önemli artıșlar yaptığını bildirmișlerdir.

Denemenin birinci yılında, mısır bitkisinde Fe birikimi en fazla köklerde saptanmıștır. Gövdede TS konusuna göre, karıșım ve atık sularda Fe birikimi, daha az olmuștur. Yaprakta birikim ise en fazla KS konusundadır. Fe'in danede birikimi, kökteki birikimle benzerlik göstermektedir. İkinci yıl ise Fe birikimi en fazla köklerde olmuș bunu, azalan sırayla gövde, yaprak ve dane izlenmiștir. Atık su ve atık su karıșımlı suların kullanıldığı konularda Fe içeriği daha yüksektir. Ancak, AS ve KS konularında kök ve gövdedeki birikimi dikkat çekicidir (Çizelge 1-4). Arıtılmıș ve atık suların yüksek demir içeriği bitkide, özellikle, dane dıșında diğer aksamlarda demir kapsamını artırmıștır.

Bakır içeriğinin, denemenin birinci yılında kök, yaprak ve danede TS konusunda, gövdede KS konusunda; denemenin ikinci yılında kökte AS+KS, gövde ve yaprakta KS, AS+KS, TS+KS, AS, TS+AS konularında, danede ise KS konusunda yüksek bulunmuștur (Çizelge 1-4). Sidle ve ark. (1976), 11 yıl atık su ile sulanan mısırda Cu ve Zn derișimini bitkide düșük, toprakta yüksek bulduklarını belirtmișlerdir. Kacar ve İnal (2008), bitkide bakır derișiminin genelde, yapraklarda diğer aksamlara göre daha 
fazla bulunduğunu açıklamıșlardır. Çinko içeriği, denemenin her iki yllında köklerde AS konusunda, yaprakta KS konusunda yüksek, gövdede denemenin birinci yllında TS+KS ve AS, ikinci yllında KS konusunda, danede ise birinci yıl TS, ikinci yll AS+KS konularında yüksek bulunmuștur. Zn birikimindeki artıș ve azalıșların, suların kirlilik yükü ile ters orantıı olduğu dikkat çekicidir (Çizelge 1-4). Jasiewicz ve ark. (2010), mısır bitkisinde farklı organlara göre çinko dağıımını inceledikleri çalıșmalarında, köklerin diğer toprak üstü organlara göre, \%34 daha fazla çinko içerdiğini ve toprak pH'sındaki artıșın çinkonun bitkiye yarayıșlığını azalttığını bildirmișlerdir. Sidle ve ark. (1976), 11 yıl atık su ile sulanan mısırda Cu ve Zn derișimini bitkide düșük; toprakta yüksek bulduklarını rapor etmișlerdir.

Mangan içeriği, denemenin ilk yılında, mısır bitkisinde en fazla gövdede birikmiștir. AS ve diğer karıșım konularında gövdede bulunan Mn değerleri oldukça yüksektir. Yaprakta ise TS ve AS konularında daha az, atık ve karıșım suların kullanıldığı konularda daha fazladır. Danede, atık su ve karıșımlı konularda Mn birikimi daha azdır. Denemenin ikinci yııında Mn içeriği, kök ve gövdede atık su ve karıșımlı konularda daha yüksektir. Kökten daneye doğru birikimde, bir azalıs söz konusudur. Ancak, danede birikim en fazla TS konusunda diğer konulara göre daha yüksektir (Çizelge 1-4).

Kurșun içeriği, birinci yllında kökte KS, yaprakta TS, danede TS konularında, denemenin ikinci yılında kökte, gövdede, yaprakta ve danede KS konusunda yüksek bulunmuștur (Çizelge 1-4). Kafadar ve Saygıdeğer (2010), atık su ile sulanan mısır bitkisinde kurșun birikimin, temiz suya göre daha fazla olduğunu ve kurșun miktarının kök>gövde>yaprak șeklinde dizilim gösterdiğini belirlemișlerdir. Baranowska ve Morek (2003), mısır köklerinde, toprak üstü organlara göre 4.5-5 kat daha fazla kurșun biriktiğini ve bitkinin kök yüzeyinde bulunan büyük miktarlarda kurșun metali alımını sınırlayan bir mekanizma olduğunu bildirmișlerdir. Pb bitkiler için gerekli değildir ve yüksek derișimler mısır için zehir etkisi yapmaktadır. Mısır bitkisi için kurșunun kritik düzeyi, $5.7 \mu \mathrm{M} / \mathrm{kg}$ olarak belirlenmiștir (Kacar ve İnal, 2008).

Nikel içeriğinin, denemenin her iki yılında da kök ve yaprakta TS konusunda, gövdede birinci yıl KS, ikinci yıl TS konusunda; danede ise birinci yll TS ve TS+AS, ikinci yıl ise KS, TS+KS konularında yüksek olduğu saptanmıștır (Çizelge 4.16-19). Elde edilen sonuçlara göre, atık su kullanımı, bitkinin Ni içeriğini artırmamıștır. Nikel birçok bitkiye 0.5-1.0 $\mathrm{mg} \mathrm{L}^{-1}$ arasında toksiktir; alkali ve nötr topraklarda toksisitesi azalmaktadır (Bașkan, 2006). Bitkide nikel (Ni) birikimi, türe göre değișir ve demir elementinin jeokimyasal özeliklerine benzerliğinden dolayı, bitkide tașınımı kolay olup yaprak ve danede (tohumda) birikir. Toksiklik düzeyi duyarlı bitkilerde 10 ppm, orta duyarlı bitkilerde 50 ppm'dir (Kacar ve İnal, 2008). Kadmiyum içeriği, denemenin birinci yılı kökte AS+KS konusunda, yaprakta ve danede TS konusunda, denemenin ikinci yllında kökte AS+KS ve KS konularında, yaprakta AS konusunda, danede KS konusunda yüksek olduğu saptanmıștır. Denemenin her iki yılında da gövdede Cd içeriğinde konular arasında farklıık saptanamamıștır (Çizelge 1-4). Kacar ve İnal (2008)'in Cutler ve Raini (1974)'den bildirdiğine göre, kadmiyum bitki dokusunda 20-100 $\mu \mathrm{M} / \mathrm{kg}$ bulunur ve kökten tepe organlara doğru gidildikçe azalır. Dimitrij ve ark. (2005), Zhu (200 1), Rui Yu-Kui ve ark. (2009) mısır danesinde, azot eklenmesine bağlı olarak, kadmiyumun arttığını belirtmișlerdir.

Alüminyum içeriği, denemenin birinci yllında kök ve gövdede TS, yapraklarda AS konularında yüksek bulunmuștur. Denemenin ikinci yılında ise bitkinin farklı organlarındaki birikimin benzer olduğu saptanmıștır (Çizelge 1-4).

Bor içeriğinin, denemenin her iki yılında da köklerde TS, danede KS konularında; birinci yıl gövdede AS, yaprakta AS+KS ve KS, ikinci yıl gövdede TS, yaprakta KS konularında yüksek olduğu anlașılmıștır (Çizelge 1-4).

\section{TARTIȘMA VE SONUCLLAR}

Hasat döneminde makro ve mikro elementler ile ağır metal analizlerine ilișkin sonuçlara göre; kentsel atık su, bitkinin hem toprak üstü aksamında hem de danede $\mathrm{N}, \mathrm{Ca}, \mathrm{Cu}$ ve $\mathrm{Pb}$ içeriklerini artırmıștır. $P, Z n$ ve $M n$ birikimi toprak üstü aksamda, Ni, Cd ve B danede, B ve K yapraklarda yüksek olarak saptanmıștır. Pb birikiminin karıșım suların bulunduğu konularda saptanamaması dikkat çekicidir. Aynı durum Cd birikiminde de söz konusudur. Cd, karıșım sularda sadece kirlilik yükü en fazla olan AS+KS konusunda, kökte saptanmıștır. Çalıșmada kullanılan atık sular ve karıșım suları, bitki aksamındaki mineral madde derișimlerini artırmaktadır. Ayrıca, ağır metallerin kökte birikmesi, mısır bitkisinin yem olarak kullanılmasında gıda güvenliği açısından, sorun olmamaktadır. Ancak, Cd'un danede birikme eğilimi, çalıșmada sınır değerlerin altında olsa bile, dikkat edilmesi gereken bir bulgudur. 
Çizelge 1. Mısır köklerinde makro, mikro element ve ağır metal derișimleri

Table 1. Concentrations of macro and micro elements, and heavy metal in the maize roots

\begin{tabular}{|c|c|c|c|c|c|c|c|c|}
\hline \multirow{2}{*}{ Yıllar } & \multirow{2}{*}{ Elementler } & \multicolumn{6}{|c|}{ Deneme konuları } & \multirow{2}{*}{$S \bar{x}$} \\
\hline & & TS & $\mathrm{TS}+\mathrm{AS}$ & AS & $\mathrm{TS}+\mathrm{KS}$ & $A S+K S$ & $\mathrm{KS}$ & \\
\hline \multirow{28}{*}{2009} & $\mathrm{~N}$ & 0.61 & 0.61 & 0.6 & 0.59 & 0.63 & 0.64 & \multirow{2}{*}{0.032} \\
\hline & $\%$ & öd & öd & öd & öd & öd & öd & \\
\hline & $P$ & 0.44 & 0.43 & 0.45 & 0.43 & 0.5 & 0.52 & \multirow{2}{*}{0.022} \\
\hline & $\%$ & $\mathrm{~b}$ & $\mathrm{~b}$ & b & b & a & a & \\
\hline & $\mathrm{K}$ & 1.95 & 1.92 & 1.95 & 1.94 & 1.85 & 1.81 & \multirow{2}{*}{0.01} \\
\hline & $\%$ & a & b & a & a & C & d & \\
\hline & Ca & 0.54 & 0.53 & 0.51 & 0.56 & 0.56 & 0.57 & \multirow{2}{*}{0.036} \\
\hline & $\%$ & a & b & b & a & a & a & \\
\hline & $\mathrm{Mg}$ & 0.26 & 0.25 & 0.27 & 0.26 & 0.39 & 0.36 & \multirow{2}{*}{0.021} \\
\hline & $\%$ & C & C & C & C & a & b & \\
\hline & $\mathrm{Fe}$ & 218.96 & 139.33 & 138.78 & 164.22 & 146.01 & 140.39 & \multirow{2}{*}{37.41} \\
\hline & ppm & a & C & C & b & C & C & \\
\hline & $\mathrm{Cu}$ & 3.4 & 2.71 & 2.35 & 2.31 & 2.28 & 2.57 & \multirow{2}{*}{0.075} \\
\hline & ppm & a & b & $\mathrm{cd}$ & d & d & bc & \\
\hline & Zn & 40.13 & 42.18 & 44.62 & 26.17 & 21.09 & 12.25 & \multirow{2}{*}{1.382} \\
\hline & ppm & C & b & a & d & e & f & \\
\hline & $\mathrm{Mn}$ & 55.2 & 55.87 & 56.46 & 55.96 & 55.37 & 40.83 & \multirow{2}{*}{0.348} \\
\hline & ppm & b & ab & a & ab & ab & C & \\
\hline & $\mathrm{Pb}$ & 0.03 & 0.19 & 0.27 & 0.30 & 0.36 & 0.67 & \multirow{2}{*}{0.062} \\
\hline & ppm & e & d & C & b & b & a & \\
\hline & $\mathrm{Ni}$ & 0.215 & 0.118 & 0.037 & 0.042 & 0.046 & 0.022 & \multirow{2}{*}{0.038} \\
\hline & ppm & a & b & C & C & C & C & \\
\hline & $\mathrm{Cd}$ & 0.0012 & 0.0011 & 0.0015 & 0.0011 & 0.0019 & 0.0009 & \\
\hline & ppm & öd & öd & öd & öd & öd & öd & 0.004 \\
\hline & $\mathrm{Al}$ & 4.02 & 2.94 & 0.81 & 0.46 & 1.09 & 1.32 & 0114 \\
\hline & ppm & a & b & d & e & $\mathrm{cd}$ & C & 0.114 \\
\hline & B & 5.96 & 3.83 & 3.58 & 4.04 & 3.87 & 0.02 & \\
\hline & ppm & a & $\mathrm{b}$ & C & $\mathrm{b}$ & $b$ & d & $0.3<4$ \\
\hline & $N$ & 0.66 & 0.64 & 0.61 & 0.63 & 0.73 & 0.79 & \\
\hline & $\%$ & C & $\mathrm{cd}$ & d & $\mathrm{cd}$ & $b$ & a & 0.01 \\
\hline & $P$ & 0.31 & 0.29 & 0.45 & 0.45 & 0.44 & 0.41 & רבק \\
\hline & $\%$ & C & C & a & a & a & $\mathrm{b}$ & $0.0 \angle Z$ \\
\hline & $\mathrm{K}$ & 0.256 & 0.279 & 0.269 & 0.273 & 0.502 & 0.561 & \\
\hline & $\%$ & b & b & b & b & a & a & 0.215 \\
\hline & Ca & 0.79 & 0.69 & 0.63 & 0.72 & 0.79 & 0.79 & \\
\hline & $\%$ & a & C & d & $\mathrm{b}$ & a & a & 0.015 \\
\hline & $\mathrm{Mg}$ & 0.31 & 0.553 & 0.753 & 0.595 & 0.757 & 0.737 & 0035 \\
\hline & $\%$ & C & b & a & b & a & a & 0.035 \\
\hline & $\mathrm{Fe}$ & 277.66 & 238.12 & 721.3 & 315.3 & 627.23 & 784.83 & \\
\hline & ppm & e & f & b & d & C & a & 0.181 \\
\hline & $\mathrm{Cu}$ & 6.91 & 6.80 & 7.17 & 7.16 & 7.27 & 6.89 & 006 \\
\hline & ppm & C & d & b & b & a & C & \\
\hline 2010 & Zn & 12.53 & 41.12 & 205.66 & 122.79 & 135.15 & 99.42 & 3756 \\
\hline & ppm & f & e & a & C & b & d & $3 . \angle 50$ \\
\hline & $\mathrm{Mn}$ & 57.73 & 105.74 & 139.71 & 139.4 & 138.57 & 162.63 & \\
\hline & ppm & f & e & b & C & d & a & 0.01 \\
\hline & $\mathrm{Pb}$ & 0.94 & 0.46 & 0.48 & 0.31 & 0.38 & 0.226 & (2) \\
\hline & ppm & b & d & C & f & e & a & 0.12 \\
\hline & $\mathrm{Ni}$ & 0.016 & 0.01 & 0.011 & 0.011 & 0.005 & 0.06 & 004 \\
\hline & ppm & a & C & b & b & d & d & \\
\hline & $\mathrm{Cd}$ & 0.21 & 0.28 & 0.31 & 0.28 & 0.26 & 0.31 & רח0 ח \\
\hline & ppm & d & b & a & b & C & a & $0.00 \angle$ \\
\hline & $\mathrm{Al}$ & 16.68 & 16.66 & 16.73 & 16.68 & 16.69 & 16.68 & 0763 \\
\hline & ppm & öd & öd & öd & öd & öd & öd & 0.263 \\
\hline & B & 1.00 & 0.50 & 0.33 & 0.66 & 0.50 & 0.001 & \\
\hline & ppm & a & C & d & $\mathrm{b}$ & C & $\mathrm{E}$ & 0.014 \\
\hline
\end{tabular}


Çizelge 2. Mısır yapraklarında makro, mikro element ve ağır metal derișimleri

Table 2. Concentrations of macro and micro elements, and heavy metal in the maize leaves

\begin{tabular}{|c|c|c|c|c|c|c|c|c|}
\hline \multirow{2}{*}{ Yıllar } & \multirow{2}{*}{ Elementler } & \multicolumn{6}{|c|}{ Deneme konuları } & \multirow{2}{*}{$S \bar{x}$} \\
\hline & & TS & $T S+A S$ & AS & $\mathrm{TS}+\mathrm{KS}$ & $A S+K S$ & KS & \\
\hline \multirow{28}{*}{2009} & $\mathrm{~N}$ & 0.690 & 0.650 & 0.660 & 0.750 & 0.810 & 0.840 & \multirow{2}{*}{0.012} \\
\hline & $\%$ & C & C & C & b & a & a & \\
\hline & $P$ & 0.570 & 0.610 & 0.480 & 0.600 & 0.470 & 0.580 & \multirow{2}{*}{0.006} \\
\hline & $\%$ & C & a & d & $a b$ & d & bc & \\
\hline & $\mathrm{K}$ & 1.190 & 1.160 & 1.990 & 1.270 & 1.310 & 1.340 & \multirow{2}{*}{0.007} \\
\hline & $\%$ & d & e & $\mathrm{f}$ & C & b & a & \\
\hline & Ca & 0.710 & 0.640 & 0.650 & 0.620 & 0.590 & 0.610 & \multirow{2}{*}{0.011} \\
\hline & $\%$ & a & b & b & C & d & C & \\
\hline & $\mathrm{Mg}$ & 0.250 & 0.170 & 0.170 & 0.270 & 0.320 & 0.330 & \multirow{2}{*}{0.008} \\
\hline & $\%$ & d & e & e & C & b & a & \\
\hline & $\mathrm{Fe}$ & 3.610 & 5.710 & 3.890 & 3.890 & 5.450 & 28.370 & \multirow{2}{*}{1.562} \\
\hline & ppm & b & b & C & C & b & a & \\
\hline & $\mathrm{Cu}$ & 5.960 & 3.900 & 4.060 & 3.160 & 3.040 & 2.550 & \multirow{2}{*}{0.023} \\
\hline & ppm & a & C & b & d & e & f & \\
\hline & $\mathrm{Zn}$ & 11.240 & 13.750 & 13.430 & 14.280 & 13.920 & 15.830 & \multirow{2}{*}{0.154} \\
\hline & ppm & d & C & C & b & bc & a & \\
\hline & $\mathrm{Mn}$ & 11.910 & 14.460 & 10.630 & 27.790 & 27.710 & 31.960 & \multirow{2}{*}{0.257} \\
\hline & ppm & d & C & e & $\mathrm{b}$ & b & a & \\
\hline & $\mathrm{Pb}$ & 0.640 & 0.400 & 0.300 & 0.250 & 0.200 & 0.210 & \multirow{2}{*}{0.021} \\
\hline & ppm & a & b & C & cd & d & d & \\
\hline & $\mathrm{Ni}$ & 0.300 & 0.280 & 0.270 & 0.260 & 0.230 & 0.190 & \multirow{2}{*}{0.003} \\
\hline & ppm & a & b & bc & C & d & e & \\
\hline & $\mathrm{Cd}$ & 0.00018 & 0.00015 & 0.00012 & 0.00016 & 0.00012 & 0.00013 & 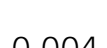 \\
\hline & ppm & öd & öd & öd & öd & öd & öd & 0.004 \\
\hline & Al & 0.090 & 0.150 & 0.210 & 0.150 & 0.150 & 0.150 & \\
\hline & ppm & C & b & a & b & b & b & 0.009 \\
\hline & B & 8.000 & 1.960 & 12.370 & 1.290 & 16.330 & 18.170 & \\
\hline & ppm & C & d & $\mathrm{b}$ & $\mathrm{b}$ & a & a & 0.997 \\
\hline & $\mathrm{N}$ & 0.742 & 0.519 & 0.571 & 0.709 & 0.729 & 0.907 & Qחת ח \\
\hline & $\%$ & b & e & d & C & $\mathrm{bc}$ & a & 0.009 \\
\hline & $P$ & 0.448 & 0.430 & 0.429 & 0.436 & 0.401 & 0.415 & \\
\hline & $\%$ & öd & öd & öd & öd & öd & öd & 0.447 \\
\hline & $\mathrm{K}$ & 1.428 & 1.486 & 1.488 & 1.319 & 1.304 & 1.200 & \\
\hline & $\%$ & b & a & a & C & C & d & 0.008 \\
\hline & Ca & 0.697 & 0.704 & 0.833 & 0.398 & 1.304 & 1.378 & \\
\hline & $\%$ & C & C & bc & $\mathrm{bc}$ & ab & a & 0.343 \\
\hline & $\mathrm{Mg}$ & 0.207 & 0.174 & 0.168 & 0.229 & 0.227 & 0.240 & רחת ח \\
\hline & $\%$ & C & d & d & $\mathrm{b}$ & b & a & 0.002 \\
\hline & $\mathrm{Fe}$ & 26.100 & 22.230 & 7.060 & 8.020 & 6.130 & 8.070 & 477 \\
\hline & ppm & a & b & e & d & f & C & $0.4 / 7$ \\
\hline & Cu & 2.440 & 3.960 & 4.190 & 4.710 & 4.760 & 5.030 & \\
\hline חנחב & ppm & b & a & a & a & a & a & 0.326 \\
\hline 2010 & $\mathrm{Zn}$ & 0.940 & 3.020 & 8.970 & 6.850 & 9.530 & 10.960 & O 240 \\
\hline & ppm & e & d & b & C & b & a & 0.244 \\
\hline & $\mathrm{Mn}$ & 32.300 & 31.240 & 27.490 & 27.980 & 29.310 & 28.550 & 236 \\
\hline & ppm & a & b & f & e & C & d & 0.236 \\
\hline & $\mathrm{Pb}$ & 0.010 & 0.024 & 0.033 & 0.029 & 0.027 & 0.040 & \\
\hline & ppm & $\mathrm{f}$ & e & b & C & d & a & 0.856 \\
\hline & $\mathrm{Ni}$ & 0.016 & 0.010 & 0.011 & 0.011 & 0.005 & 0.006 & \\
\hline & ppm & a & C & $\mathrm{bc}$ & $\mathrm{b}$ & d & d & 0.193 \\
\hline & $\mathrm{Cd}$ & 0.017 & 0.150 & 0.106 & 0.159 & 0.106 & 0.137 & 414 \\
\hline & ppm & d & a & C & a & C & b & 0.014 \\
\hline & $\mathrm{Al}$ & 16.670 & 16.680 & 16.170 & 16.660 & 16.690 & 16.690 & هo 10 \\
\hline & ppm & öd & öd & öd & öd & öd & öd & 0.199 \\
\hline & B & 7.660 & 18.660 & 62.330 & 79.660 & 66.330 & 88.330 & 0.504 \\
\hline & ppm & $\mathrm{f}$ & e & d & b & C & a & 0.504 \\
\hline
\end{tabular}


Çizelge 3. Mısır gövdesinde makro, mikro element ve ağır metal derișimleri

Table 3. Concentrations of macro and micro elements, and heavy metal in the maize stem

\begin{tabular}{|c|c|c|c|c|c|c|c|c|}
\hline \multirow{2}{*}{ Yillar } & \multirow{2}{*}{ Elementler } & \multicolumn{6}{|c|}{ Deneme Konuları } & \multirow{2}{*}{$S \bar{X}$} \\
\hline & & TS & TS+AS & AS & $\mathrm{TS}+\mathrm{KS}$ & $A S+K S$ & KS & \\
\hline \multirow{28}{*}{2009} & $\mathrm{~N}$ & 0.230 & 0.210 & 0.370 & 0.350 & 0.400 & 0.440 & \multirow{2}{*}{0.027} \\
\hline & $\%$ & d & d & C & C & b & a & \\
\hline & $P$ & 0.289 & 0.290 & 0.290 & 0.290 & 0.250 & 0.270 & \multirow{2}{*}{0.005} \\
\hline & $\%$ & öd & öd & öd & öd & öd & öd & \\
\hline & K & 1.230 & 1.210 & 1.200 & 1.180 & 1.080 & 1.100 & \multirow{2}{*}{0.008} \\
\hline & $\%$ & a & ab & bc & C & d & d & \\
\hline & Ca & 0.187 & 0.205 & 0.126 & 0.106 & 0.130 & 1.139 & \multirow{2}{*}{0.012} \\
\hline & $\%$ & b & $a b$ & C & f & e & a & \\
\hline & $\mathrm{Mg}$ & 0.400 & 0.350 & 0.370 & 0.270 & 0.300 & 0.280 & \multirow{2}{*}{0.002} \\
\hline & $\%$ & a & C & bc & f & d & e & \\
\hline & $\mathrm{Fe}$ & 44.140 & 43.300 & 39.260 & 39.080 & 34.580 & 32.220 & \multirow{2}{*}{2.765} \\
\hline & ppm & a & ab & abc & abc & bc & C & \\
\hline & $\mathrm{Cu}$ & 0.770 & 0.740 & 0.740 & 2.170 & 2.520 & 4.770 & \multirow{2}{*}{0.041} \\
\hline & ppm & d & d & d & C & b & a & \\
\hline & $\mathrm{Zn}$ & 32.420 & 32.960 & 35.750 & 36.290 & 34.000 & 22.000 & \multirow{2}{*}{0.600} \\
\hline & ppm & C & bc & a & a & b & d & \\
\hline & $\mathrm{Mn}$ & 101.630 & 102.560 & 103.570 & 103.910 & 103.210 & 96.960 & \multirow{2}{*}{0.518} \\
\hline & ppm & b & ab & a & a & ab & C & \\
\hline & $\mathrm{Pb}$ & 0.010 & 0.180 & 0.350 & 0.410 & 0.270 & 0.110 & \multirow{2}{*}{0.009} \\
\hline & ppm & f & d & b & a & C & e & \\
\hline & $\mathrm{Ni}$ & 0.080 & 0.090 & 0.090 & 0.110 & 0.110 & 0.130 & \multirow{2}{*}{0.013} \\
\hline & ppm & C & C & C & b & b & a & \\
\hline & $\mathrm{Cd}$ & 0.032 & 0.020 & 0.035 & 0.030 & 0.030 & 0.030 & 0,0 \\
\hline & ppm & öd & öd & öd & öd & öd & öd & 0.04 \\
\hline & $\mathrm{Al}$ & 0.660 & 0.470 & 0.030 & 0.030 & 0.020 & 0.020 & 0.072 \\
\hline & ppm & a & bc & C & C & C & C & $0.0 \angle Z$ \\
\hline & B & 16.000 & 20.420 & 23.000 & 22.250 & 21.040 & 21.450 & ( 800 \\
\hline & ppm & C & $\mathrm{bc}$ & a & ab & $\mathrm{ab}$ & $a b$ & 0.800 \\
\hline & $N$ & 0.414 & 0.584 & 0.570 & 0.547 & 0.748 & 0.784 & \\
\hline & $\%$ & f & C & d & e & b & a & 0.013 \\
\hline & $P$ & 0.307 & 0.294 & 0.308 & 0.312 & 0.307 & 0.309 & \\
\hline & $\%$ & ns & ns & ns & ns & ns & ns & 0.398 \\
\hline & $\mathrm{K}$ & 0.255 & 0.208 & 0.283 & 0.225 & 0.281 & 0.313 & רח0 0 \\
\hline & $\%$ & C & e & b & d & b & a & $0.00 \angle$ \\
\hline & $\mathrm{Ca}$ & 0.704 & 0.553 & 0.505 & 0.917 & 1.031 & 1.780 & 0071 \\
\hline & $\%$ & d & e & e & C & b & a & $0.0 / 1$ \\
\hline & $\mathrm{Mg}$ & 0.227 & 0.208 & 0.246 & 0.229 & 0.261 & 0.248 & \\
\hline & $\%$ & b & C & a & b & a & a & 0.006 \\
\hline & $\mathrm{Fe}$ & 0.140 & 52.100 & 122.610 & 72.790 & 70.130 & 124.980 & O 380 \\
\hline & ppm & f & e & b & C & d & a & 0.389 \\
\hline & $\mathrm{Cu}$ & 4.720 & 7.410 & 7.430 & 7.310 & 7.620 & 6.880 & \\
\hline 2010 & ppm & b & a & a & a & a & a & 0.570 \\
\hline 2010 & Zn & 10.580 & 19.190 & 18.480 & 19.920 & 19.540 & 26.250 & 0516 \\
\hline & ppm & C & b & b & b & b & a & 0.510 \\
\hline & $\mathrm{Mn}$ & 109.210 & 109.100 & 111.810 & 110.620 & 111.430 & 112.470 & 487 \\
\hline & ppm & öd & öd & öd & öd & öd & öd & 4.82 \\
\hline & $\mathrm{Pb}$ & 0.156 & 0.038 & 0.059 & 0.045 & 0.052 & 0.630 & \\
\hline & ppm & b & f & C & e & d & a & 0.06 \\
\hline & $\mathrm{Ni}$ & 0.092 & 0.057 & 0.009 & 0.010 & 0.007 & 0.006 & 00015 \\
\hline & ppm & a & b & C & C & d & e & 0.0015 \\
\hline & $\mathrm{Cd}$ & 0.113 & 0.158 & 0.035 & 0.055 & 0.080 & 0.081 & 041 \\
\hline & ppm & ns & ns & ns & ns & $\mathrm{ns}$ & $\mathrm{ns}$ & 0.41 \\
\hline & $\mathrm{Al}$ & 16.690 & 16.670 & 16.660 & 16.700 & 16.690 & 16.710 & 0327 \\
\hline & ppm & öd & öd & öd & öd & öd & öd & 0.332 \\
\hline & B & 21.170 & 19.330 & 17.660 & 18.660 & 4.500 & 5.000 & 138 \\
\hline & ppm & a & $b$ & $\mathrm{C}$ & $\mathrm{b}$ & d & d & 1.38 \\
\hline
\end{tabular}


Çizelge 4. Mısır danesinde makro, mikro element ve ağır metal derișimleri

Table 4. Concentrations of macro and micro elements, and heavy metal in the maize grain

\begin{tabular}{|c|c|c|c|c|c|c|c|c|}
\hline \multirow{2}{*}{ Yillar } & \multirow{2}{*}{ Elementler } & \multicolumn{6}{|c|}{ Deneme Konuları } & \multirow{2}{*}{$S \bar{x}$} \\
\hline & & TS & TS+AS & AS & $\mathrm{TS}+\mathrm{KS}$ & $A S+K S$ & KS & \\
\hline \multirow{28}{*}{2009} & $N$ & 3.040 & 2.930 & 3.070 & 2.940 & 3.180 & 3.210 & \multirow{2}{*}{0.061} \\
\hline & $\%$ & $a b$ & b & $a b$ & b & a & a & \\
\hline & $P$ & 0.520 & 0.580 & 0.580 & 0.610 & 0.380 & 0.400 & \multirow{2}{*}{0.006} \\
\hline & $\%$ & C & b & b & a & e & d & \\
\hline & $\mathrm{K}$ & 0.310 & 0.290 & 0.240 & 0.260 & 0.240 & 0.230 & \multirow{2}{*}{0.004} \\
\hline & $\%$ & a & b & d & C & de & e & \\
\hline & Ca & 0.490 & 0.500 & 0.520 & 0.570 & 0.710 & 1.310 & \multirow{2}{*}{0.009} \\
\hline & $\%$ & d & d & d & C & b & a & \\
\hline & $\mathrm{Mg}$ & 0.110 & 0.191 & 0.225 & 0.269 & 0.290 & 0.310 & \multirow{2}{*}{0.009} \\
\hline & $\%$ & e & d & C & b & $a b$ & a & \\
\hline & $\mathrm{Fe}$ & 34.990 & 29.770 & 27.550 & 18.550 & 18.300 & 18.240 & \multirow{2}{*}{1.044} \\
\hline & ppm & a & b & b & C & C & C & \\
\hline & $\mathrm{Cu}$ & 1.410 & 1.310 & 1.180 & 0.960 & 1.310 & 1.290 & \multirow{2}{*}{0.045} \\
\hline & ppm & a & ab & b & C & ab & ab & \\
\hline & Zn & 23.710 & 20.690 & 20.940 & 19.040 & 14.330 & 12.830 & \multirow{2}{*}{0.288} \\
\hline & ppm & a & b & b & C & d & e & \\
\hline & $\mathrm{Mn}$ & 26.420 & 21.790 & 11.870 & 7.210 & 10.050 & 3.830 & \multirow{2}{*}{0.361} \\
\hline & ppm & a & b & c & e & d & f & \\
\hline & $\mathrm{Pb}$ & 0.282 & 0.128 & 0.090 & 0.069 & 0.060 & 0.036 & \multirow{2}{*}{0.004} \\
\hline & ppm & a & b & C & d & d & e & \\
\hline & $\mathrm{Ni}$ & 0.220 & 0.210 & 0.150 & 0.156 & 0.126 & 0.089 & \multirow{2}{*}{0.011} \\
\hline & ppm & a & a & b & b & bc & C & \\
\hline & $\mathrm{Cd}$ & 23.330 & 21.670 & 11.670 & 6.620 & 10.000 & 9.000 & \\
\hline & ppm & a & b & C & f & d & e & 0.004 \\
\hline & $\mathrm{Al}$ & 0.051 & 0.043 & 0.042 & 0.039 & 0.046 & 0.049 & \\
\hline & ppm & öd & öd & öd & öd & öd & öd & 0.114 \\
\hline & B & 1.170 & 7.250 & 7.420 & 7.210 & 7.670 & 13.040 & 0370 \\
\hline & ppm & $\mathrm{C}$ & $\mathrm{b}$ & $\mathrm{b}$ & $\mathrm{b}$ & $\mathrm{b}$ & a & 0.310 \\
\hline & $N$ & 3.670 & 2.870 & 2.720 & 2.990 & 3.120 & 3.940 & \\
\hline & $\%$ & b & e & f & d & C & a & $0.0<1$ \\
\hline & $P$ & 0.680 & 0.694 & 0.609 & 0.851 & 0.667 & 0.673 & \\
\hline & $\%$ & bc & b & d & a & C & bc & 0.006 \\
\hline & $\mathrm{K}$ & 0.933 & 0.723 & 0.815 & 0.800 & 0.881 & 0.818 & \\
\hline & $\%$ & a & d & C & C & b & C & 0.012 \\
\hline & Ca & 0.036 & 0.023 & 0.081 & 0.029 & 0.039 & 0.132 & 0003 \\
\hline & $\%$ & $\mathrm{~cd}$ & e & b & de & C & a & 0.003 \\
\hline & $\mathrm{Mg}$ & 0.125 & 0.154 & 0.233 & 0.235 & 0.181 & 0.244 & 0014 \\
\hline & $\%$ & C & bc & a & a & b & a & 0.014 \\
\hline & $\mathrm{Fe}$ & 0.080 & 1.310 & 2.921 & 3.196 & 2.988 & 3.136 & \\
\hline & ppm & C & b & a & a & a & a & $0.1<0$ \\
\hline & Cu & 0.810 & 1.278 & 1.637 & 1.840 & 2.246 & 2.706 & \\
\hline & ppm & e & d & C & C & b & a & 0.098 \\
\hline 2010 & $\mathrm{Zn}$ & 20.490 & 18.140 & 19.310 & 21.540 & 22.170 & 17.910 & 0445 \\
\hline & ppm & bc & d & $c d$ & ab & a & d & 0.445 \\
\hline & $\mathrm{Mn}$ & 26.42 a & $21.79 \mathrm{~b}$ & $11.87 \mathrm{C}$ & $7.21 \mathrm{e}$ & $10.05 \mathrm{~d}$ & $3.83 \mathrm{f}$ & 0.348 \\
\hline & ppm & a & b & C & e & d & f & \\
\hline & $\mathrm{Pb}$ & 0.009 & 0.021 & 0.086 & 0.087 & 0.074 & 0.118 & 0004 \\
\hline & ppm & f & e & C & b & d & a & 0.004 \\
\hline & $\mathrm{Ni}$ & 0.020 & 0.020 & 0.019 & 0.020 & 0.018 & 0.019 & ר०० \\
\hline & ppm & öd & öd & öd & öd & öd & öd & $0.00 \%$ \\
\hline & $\mathrm{Cd}$ & 0.169 & 0.496 & 0.666 & 0.508 & 0.740 & 0.859 & 0700 \\
\hline & ppm & e & d & C & d & b & a & $0.0<0$ \\
\hline & $\mathrm{Al}$ & 16.670 & 16.660 & 16.660 & 16.670 & 16.670 & 16.690 & 0331 \\
\hline & ppm & ns & ns & ns & ns & $\mathrm{ns}$ & $\mathrm{ns}$ & 0.331 \\
\hline & B & 12.670 & 24.000 & 24.170 & 18.170 & 22.330 & 24.330 & 0014 \\
\hline & ppm & $\mathrm{f}$ & $C$ & b & $\mathrm{e}$ & d & a & 0.014 \\
\hline
\end{tabular}


Konya ili kentsel atık sularının tarımda kullanılabilmesi için farklı seçenekler dikkate alınarak (arıtma, kısmen arıtma ve seyreltme) kirletici ölçütleri farklı sulunan bitkinin organları incelenmiș așağıdaki sonuçlara ulașılmıștır.

Denemede kullanılan sular, $\mathrm{pH}$ yönünden sulama açısından herhangi bir sorun olușturmazken, elektriksel iletkenlik, SAR ve tuzluluk değerleri, kullanımı kısıtlamaktadır. Karıșım sularının hemen hepsinin "ihtiyatla kullanılabilir" T3Al (yüksek tuzlu ve düșük sodyum zararı) sınıfında olduğu anlașılmıștır. Bu sonuçlara göre araștırmada ele alınan atık su ve karıșım suları, tuzluluk bakımından, kötü nitelikli sulardır ve sulamada kullanılması durumunda, tarım topraklarında tuzluluksodyumluk sorunlarının ortaya çıkmasına neden olacak potansiyeldedir. Bu nedenle, sulama yönetimine göre su kalitesinin izlenmesi ve iyileștirilmesi amacıyla iyi nitelikli sularla karıștırılıp seyreltilerek kullanılması gereklidir. Ayrıca, temiz su kaynağının yetersiz olduğu ve atık su kaynaklı suların kullanılması durumunda, etkin tuzluluk ve toprak bünyesine göre potansiyel tuzluluk değerleri dikkate alınarak kontrollü olarak kullanılmalıdır.

AKM, KOI, BOI, Toplam N, Toplam P ve Toplam Fekal Koliform gibi ölçütlere göre; denemede kullanılan atık suların tümü (TS+AS dıșında), yönetmelik sınır değerlerinin üstünde değerler tașımaktadır. Özellikle patojenler ve diğer atık su ölçütlerinin yüksekliği, insan ve çevre sağlığını korumada en gerçekçi ve etkin önlem olarak atık su arıımını zorunlu kılmaktadır.

Deneme sularında $\mathrm{Cu}, \mathrm{Fe}, \mathrm{Mn}$ ve $\mathrm{Zn}$ derișimleri, kritik değerlerin altında bulunmaktadır. Suların B değerlerinin mısır gibi orta derecede dayanıklı bitkiler için II. Sınıf (iyi) olduğu anlașılmaktadır. Öte

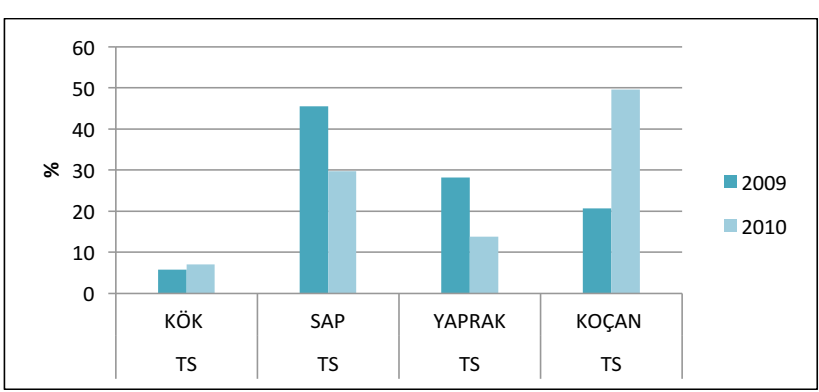

Șekil 1. TS konusunda bitki organlarında biyokütle oranı (YGS 203)

Figure 1. The percentage of biomass in plant organs for TS. yandan ağır metal kapsamları Pb, Ni değerleri, yönetmelik sınır değerlerinin altında bulunmuștur. Cd değerleri, kimi zamanlarda AS, TS+KS, AS+KS ve KS konularında yönetmelik sınır değerinden yüksektir. Deneme sularında $\mathrm{Ag}, \mathrm{Ba}, \mathrm{Be}, \mathrm{Co}$, $\mathrm{Cr}$, Li, Mo, ağır metalleri bulunmamaktadır. Endüstriyel atık suların arıtılması, patojenik ve diğer potansiyel toksik bileșiklerin kabul edilebilir sınırlara indirilmesinde ya da elimine edilmesinde önemlidir. Bu nedenle endüstriyel paket arıtım ünitelerinin kurulması gereklidir.

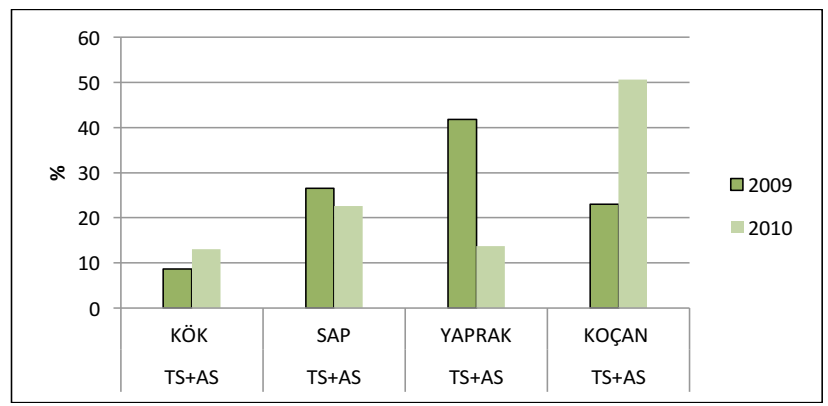

Șekil 2. TS+AS konusunda bitki organlarında biyokütle oranı (YGS 203)

Figure 2. The percentage of biomass in plant organs for $T S+A S$.

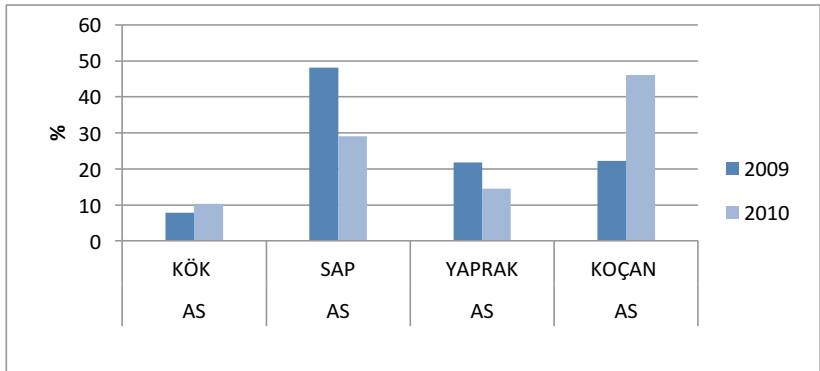

Șekil 3. AS konusunda bitki organlarında biyokütle oranı (YGS 203)

Figure 3. The percentage of biomass in plant organs for AS.

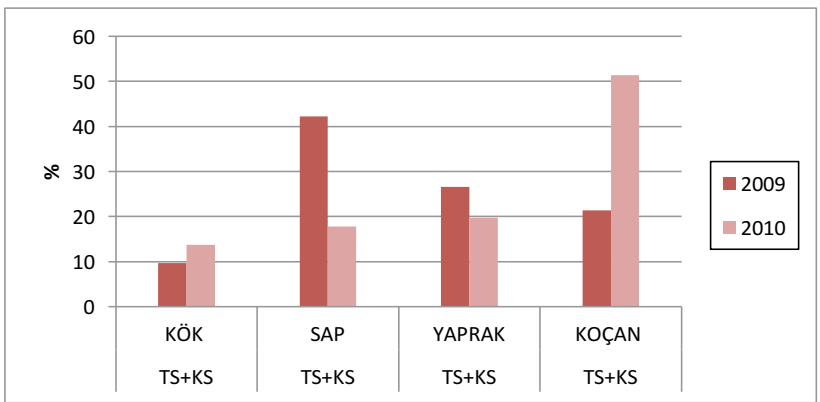

Șekil 4. TS+KS konusunda bitki organlarında biyokütle oranı (YGS 203)

Figure 4. The percentage of biomass in plant organs for $T S+K S$. 


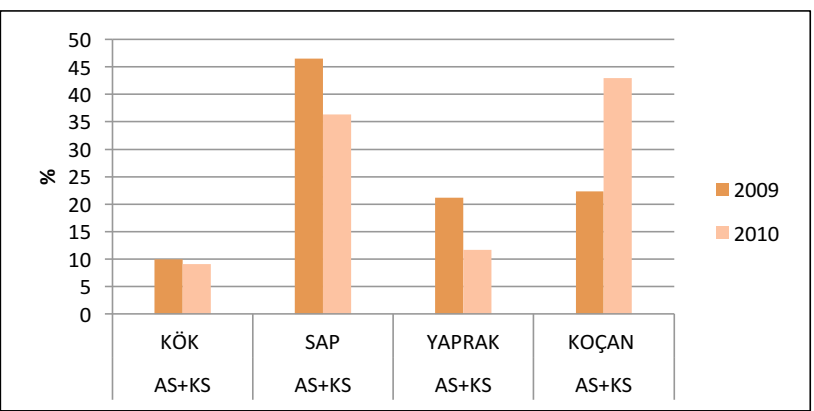

Sekil 5. TS+KS konusunda bitki organlarında biyokütle oranı (YGS 203)

Figure 5. The percentage of biomass in plant organs for $T S+K S$.

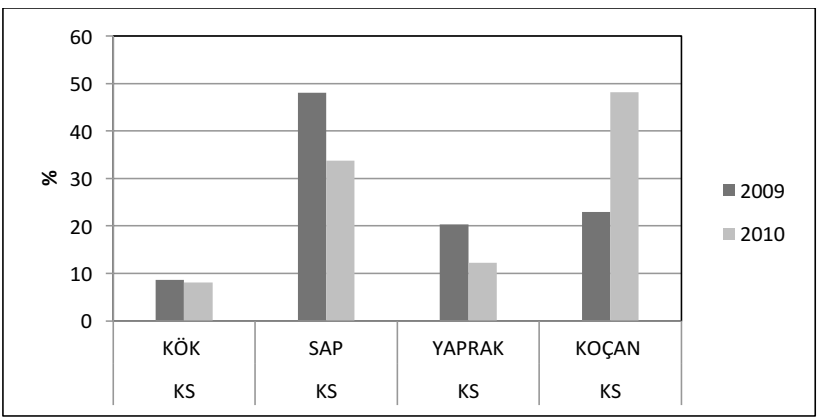

Șekil 6. KS konusunda bitki organlarında biyokütle oranı (YGS 203)

Figure $\mathbf{6}$. The percentage of biomass in plant organs for KS.

\section{KAYNAKLAR}

Baranowska Morek, A (2003). Plant mechanisms of tolerance to the tonic effect of heavy metals. Kosmos. Probl. Nauk Biol., 52 (2): 283-298.

Çay Ș (2013). Konya kentsel atık sularının tarımsal sulamada kullanılması ve mısır yetiștiriciliğine etkileri. Doktora Tezi. Çukurova Üniversitesi Fen Bilimleri. Adana.

Çay Ș, Kanbger R (2013) Konya kentsel atık sularının tarımsal sulamada kullanılması ve mısır yetiștiriciliğine etkileri. TAGEM 2013-51 Proje Sonuç Raporu. 66-74.
Day AD, Tucker TC (1977). Effects of treated wastewater on growth, fibre, protein and amino acid content of sorghum grains. Journal of Environmental Quality. Vol. 6 (3):3 25-327.

Dmitrij I, Bashmakov AS, Lukatkin V, Revin V, Povilas D, Brazaityte A, Baranauskıs K (2005). Growth of maize seedlings affected by different concentrations of heavy metals. Ekologij, 3: $22-27$

Eid MA, Shereif M (1996). Effect of waste water iririgation on rowth and mineral contents of certain crops. Egypt. J.of Soil. Sci., $36(1-4): 109-118$.

Jasiewıcz CZ, Baran A, Tarnawski M (2010). Effect of bottom sediment on content, bioaccumulation and translocation of heavy metals in maize biomass. J. Elem. 15(2):281-290.

Kacar B, İnal A (2008). Bitki analizleri. 3. Nobel Yayın Dağtım. s: 912.

Kacar B, Katkat AV (1998). Bitki besleme. 3. Baskı. Uludağ Üniversitesi Güçlendirme Vakfı Yayınları, 127:168-175.

Kafadar FN, Saygıdeğer S (2010). Gaziantep ilinde organize sanayi bölgesi atık suları ile sulanan bazı tarım bitkilerinde kurșun (pb) miktarlarının belirlenmesi. Ekoloji, 19(75): 41-48.

Marten GC, Larson WE, Clapp CE (1980). Effects of municipal wastewater effluent on performance and feed quality of maize vs. reed canarygrass. Journal of Environmental Quality, 9 (1): 137-141.

Sidle RC, Hook JE, Kardos LT, (1976). Heavy metals application and plant uptake in a land disposal system for wastewater. Journal of Environmental Quality, 5: 97-102.

Tuna AL, Bürün B, Șahin O, Yağmur B (2001). Kentsel atık suların yeniden değerlendirilmesi. IV Ulusal Çevre Kongresi 5-8 Ekim 2001 Bodrum, s.513-518.

Tuna AL, Bürün B (2003). Mısırda mineral beslenme ve bazı topraközellikleri üzerine kentsel atık suların etkisi. Dumlupınar Üni. Fen Bilimleri Dergisi, 4:7-15.

Tuna AL, Girgin AR (2005). (Zea mays L.) gelisme, mineral beslenme ve ağır metal ıçeriği üzerine termik santral uçucu küllerinin etkisi. Ekoloji, 14(57): 29-37. 